ESJ Natural/Life/Medical Sciences

\title{
Coffee Berry Borer, Hypothenemus Hampei Ferr.: Cultural Control and In Vitro Effects of Kernel Extracts of Azadirachta indica A. Juss. and Thevetia peruviana (Pers.) Schum
}

\section{Manga Essouma François}

Central Laboratory of Phytopathology, Mbalmayo Agricultural Research Centre, Institute of Agricultural Research for the Development (IRAD), Yaoundé, Cameroon

Laboratory of Phytopathology, Department of Plant Biology, University of Yaoundé 1, Yaoundé, Cameroon

Voula Valteri Audrey

Central Laboratory of Entomology, Mbalmayo Agricultural Research Centre, Institute of Agricultural Research for the Development (IRAD), Yaoundé,

Cameroon

Laboratory of Zoology, Department of Biology of Animal Organisms, Faculty of Sciences, University of Yaoundé I, Yaoundé, Cameroon

\section{Kone Nsangou Abdou Nourou}

Laboratory of Phytopathology, Department of Plant Biology, University of Yaoundé 1, Yaoundé, Cameroon

Research Unit of Applied Botany, Department of Plant Biology, University

of Dschang, Dschang, Cameroon

Mvondo Nganti Dorothée Ambang Zachée

Laboratory of Phytopathology, Department of Plant Biology, University of Yaoundé 1, Yaoundé, Cameroon

Doi:10.19044/esj.2021.v17n34p12

Submitted: 12 January 2021

Accepted: 10 August 2021

Published: 30 September 2021
Copyright 2021 Author(s)

Under Creative Commons BY-NC-ND 4.0 OPEN ACCESS

Cite As:

Manga Essouma F., Voula Valteri A., Kone Nsangou A.N., Mvondo Nganti D. \& Ambang Z. (2021). Coffee Berry Borer, Hypothenemus Hampei Ferr.: Cultural Control and In Vitro Effects of Kernel Extracts of Azadirachta indica A. Juss. and Thevetia peruviana (Pers.) Schum. European Scientific Journal, ESJ, 17(34), 12.

https://doi.org/10.19044/esj.2021.v17n34p12 


\begin{abstract}
The coffee berry borer, Hypothenemus hampei, is one of the most important coffee berry borer pests in the world, reaching attack rates of 10$100 \%$ in Cameroon. The objective of this study is to evaluate the efficacy of crop control and the effects of aqueous extracts of Thevetia peruviana kernel powder and aqueous extracts, and oil of Azadirachta indica kernel powder against this insect. Crop control was firstly achieved by sanitary harvesting of bark beetle-infested berries and, secondly, by the installation of a network of home-made pheromone traps. The bark beetles were breeding in the laboratory and tests were also carried out on substitute foodstuffs such as maize and groundnuts. The efficacy of pesticidal plant extracts at four concentrations each was evaluated by direct applications of these on bark beetles and berries. The results showed that the reproduction rate of the borer was 11 times higher with coffee berries than with maize and groundnuts. After the direct treatment of the bark beetles, the aqueous extracts of T. peruviana showed a significantly average efficiency on the mortality of the bark beetles ranging from $0 \%$ to 94.9\% of bark beetles killed. Oil extracts of A. indica and chlorpyrifos-ethyl (Pyriforce) were more effective against bark beetles with average mortality rates ranging from 78.7 to $100 \%$. After direct treatment of the berries, oil and aqueous extracts of $\mathrm{A}$. indica and chlorpyrifos-ethyl were the most effective treatments causing more than 50\% mortality of the bark beetles. Oil of $\mathrm{A}$. indica and aqueous extracts of T. peruviana can therefore be used in the same way as pyriforce in the protection of coffee plants against H. hampei.
\end{abstract}

Keywords: Hypothenemus hampei, Pesticidal Plants, Biological Control, Coffea sp.

\title{
1. Introduction
}

More than US\$30 billion worth of pesticides are voluntarily dumped into the wild each year worldwide for crop protection (PAN, 2008). The intensive use of these products has not spared Cameroon, which also promotes "second-generation agriculture" in the agricultural policy of the Growth and Employment Strategy Paper (DSCE). This DSCE refers to mechanised agriculture that is commercial and intensive in chemical inputs (Minepat, 2009; Bayiha et al., 2020). For example, the cultivation of coffee trees, an agricultural export product contributing to the improvement of producers' incomes and Cameroon's gross domestic product (GDP) (Mbondji, 1988; Mahob et al., 2006), is not spared by the intensive use of chemical pesticides. Thus, endosulfan and chlorpyrifos-ethyl (chemical insecticides) are used to control the world's largest berry pest, Hypothenemus hampei (Ferrari) (Coleoptera: Scolytidae) (Amang-Mbang et al., 2012). 
Despite this intensive use of chemical pesticides and the Cameroon's efforts through the Plan for the Recovery and Development of the Cocoa/Coffee Sectors (PRDCCS), the coffee production continues to decrease considerably (Anonymous, 2014). This production reached 27,797 tons of Robusta coffee and 7,418 tons of Arabica coffee in 2020 (Ecofin Agency, 2020), far behind the forecasts of the PRDCCS (with a prospective vision of 125,000 tons of Robusta coffee and 35,000 tons of Arabica coffee from 2015 to 2020) (Anonymous, 2014). This gap is due to bad agricultural practices and strong attacks from diseases including Colletotrichum kahawae (pathogen agent causing anthracnose berry disease) and insects such as the coffee berry borer, $H$. hampei (Anonymous, 2014).

With regard to pests, the berry borer (H. hampei), native to Africa (Perez-Lachaud et al., 2002), is one of the most important coffee pests in the world (Vega et al., 2015), reaching attack rates of $10-100 \%$ in Cameroon (Mahob et al., 2006). Due to its endophytic lifestyle in coffee berries throughout its life cycle (Cochereau \& Potiaroa, 1994; Dufour, 2013), attempts to control this insect chemically with the use of chlorpyriphos-ethyl and endosulfan (Damon, 2000; Aristizabal et al., 2012) remain interesting but limited. Similarly, the risks to human health and the environment, and the high persistence of the active ingredients of these chemical pesticides, are today at the origin of their total ban in agriculture (PAN, 2008).

To monitor their use, it is essential today to promote agro-ecology and organic farming through the use of natural products in agricultural production. In this perspective, cultural control with sanitary harvesting (Dufour \& Frérot, 2008) or biological control with the use of pesticidal plant extracts (NguemaNdoutoumou et al., 2015; Samy, 2018) have shown interesting effects against the coffee berry borer. With the aim of providing coffee producers with other palliative solutions to chemical pesticides that are less costly, more respectful of the environment and human health and guarantee quality coffee production, this study had the following objectives: (i) to evaluate the effectiveness of sanitary harvesting of berries infested with bark beetles and the use of pheromone traps; (ii) to evaluate the effectiveness of using aqueous extracts of Thevetia peruviana kernels, aqueous extracts and oil of Azadirachta indica kernels against this bark beetle; and (iii) to assess the influence of the application mode of the treatments on their effectiveness against $H$. hampei.

\section{Materials And Methods}

\subsection{Study Sites}

The berries and bark beetles were collected in the woodlots of the Institute of Agricultural Research for Development (IRAD) stations located in the localities of Foumbot (Latitude $05^{\circ} 29^{\prime} 034^{\prime \prime}$ and Longitude 010 33 '33.0"; altitude $1,240 \mathrm{~m}$ to $2,740 \mathrm{~m}$; mean annual temperatures $19{ }^{\circ} \mathrm{C}$ ) and 
Nkoémvone ( $2^{\circ} 90$ of latitude North to $12^{\circ} 2$ of longitude East; altitude 500 and $1,000 \mathrm{~m}$; mean annual temperatures $25^{\circ} \mathrm{C}$ ) (IRAD, 2008). The tests were carried out in the Phytopathology and Entomology Laboratories of the IRAD, located in Yaoundé, Cameroon.

\subsection{Hunting of Coffee Berry Borers and Breeding in the Laboratory}

The adult insects of Hypothenemus hampei, from laboratory breeding, were used in the experimental tests. However, the initial population of bred insects was obtained on the one hand by harvesting bark beetle-infested berries, and on the other hand, through a network of home-made traps installed in the coffee fields.

The traps were made from an empty mineral water bottle that had been cut out and the upper part was turned over and nested in the lower part of the bottle. A small bottle of about $4 \mathrm{ml}$ containing a solution of ethanol and methanol (proportion 1:1) (Figure 1A) was hung inside and the whole thing was held on the coffee tree with a wire, i.e., 36 traps per hectare (Figure $1 \mathrm{~B} \&$ 1C). This model was adapted to the BROCAP model (Dufour \& Frérot, 2008).

The insects collected were identified with a magnifying glass on the basis of the identification characters defined by Vega et al. (2015). The observations made were confirmed by the observation of the collection boxes from the Entomological Conservatory of the Entomology Laboratory of the Mbalmayo Agricultural Research Centre.
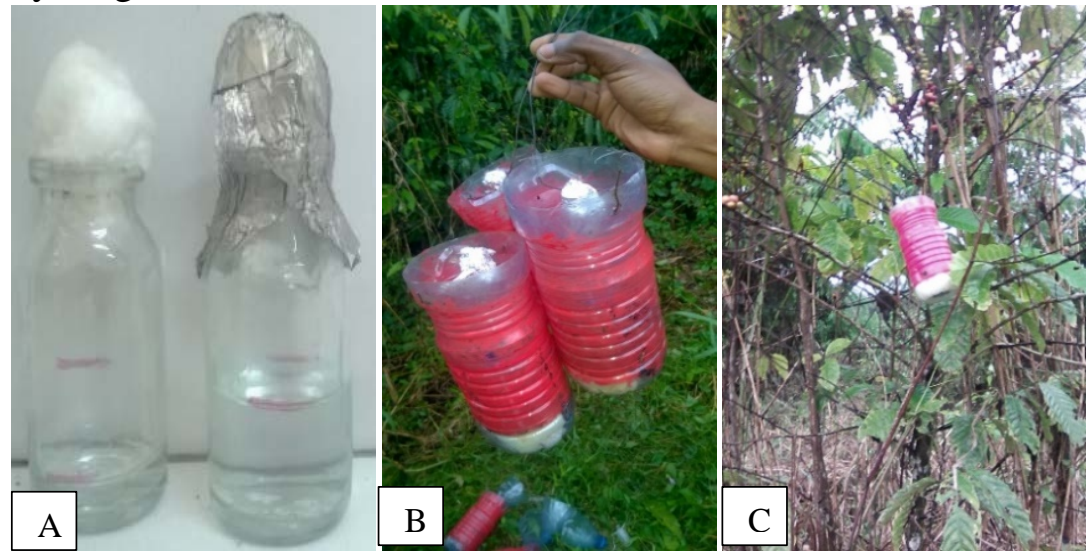

Figure 1. Manufacture of the Artisanal Trap for Hunting Bark Beetles

A: Bottle Containing the Pheromones; $\mathbf{B}$ and $\mathbf{C}$ : Traps Made and Hung on the Coffee Tree

For coffee berry borer rearing, about $5 \mathrm{~kg}$ of fresh and healthy berries (semi-ripe and ripe) were harvested and distributed in 04 buckets (20 litres) covered with muslin. A population of about 300 live coffee berry borers was removed from these buckets and placed in jars ( $22.5 \times 14.5 \times 5.5 \mathrm{~cm}$ volume) at a rate of 30 berry borers per jar with 30 healthy cherries (Figure 2). After 21-30 days of incubation of the insects (corresponding to the complete life 
cycle of the coffee berry borer under artificial conditions), at a temperature of $25 \pm 2{ }^{\circ} \mathrm{C}$, new generations of coffee berry borers were produced (Dufour \& Frérot, 2008; Vega et al., 2015). Fresh and healthy berries were added weekly in the buckets.

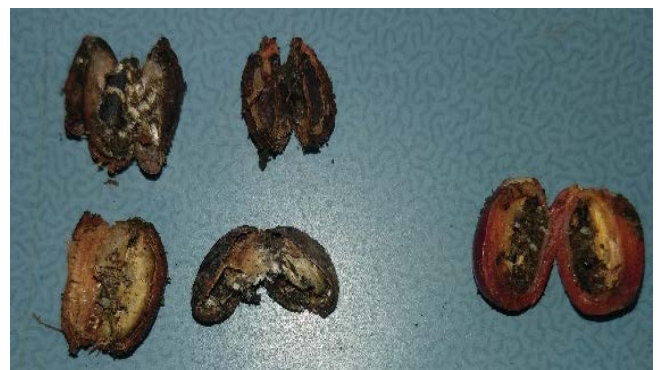

Figure 2. Harvest of Bark Beetles from Infested Berries

Other tests were carried out on alternative foods that could help to produce and maintain the borer population after the coffee season. For this purpose, semi-dry groundnut and maize kernels were used as a food source compared to coffee berries. Therefore, $100 \mathrm{~g}$ of each food were placed in 5 jars $(22.5 \times 14.5 \times 5.5 \mathrm{~cm}$ in volume $)$ and 15 insects including 5 males and 10 females were placed in each jar. These jars were randomly placed in the insectarium at $25 \pm 2{ }^{\circ} \mathrm{C}$ for a photoperiod of $12: 12$ and the insects were counted in each substrate according to sex after 43 days.

From the number of male and female insects obtained, the reproduction rate as well as the sex ratio were calculated using the formula:

$$
R r=\frac{F F}{I P} \quad ; \quad S r=\frac{N M}{N F}
$$

Rr: reproduction rate; FP: final population obtained; IP: initial population; Sr: sex ratio;

NM: number of males obtained; NF: number of females obtained

\subsection{In Vitro Assessment of the Insecticidal Activity of Plant Extracts on Hypothenemus hampei}

\subsubsection{Obtaining and Preparing the Various Extracts and Test Doses}

The already dried kernels of the ripe neem (Azadirachta indica) fruit were obtained in the Far North region of Cameroon. For the yellow laurel (Thevetia peruviana), the ripe kernels were collected in the Central Cameroon region, locality of Yaoundé and its surroundings. Subsequently, these fruits were manually stripped of their shells. In the laboratory, the kernels of the two pesticide-treated plants were dried at room temperature for three weeks, then cleaned and finely crushed using a manual grinder. The powders thus obtained and stored in opaque glass vials allowed the preparation of the aqueous extracts. Purchased, the neem oil was traditionally hot extracted and sold by the women on the local market of Dana, in the district of Kaélé, department of Mayo-Kani, region of Far North Cameroon. 
Referring to Stoll's (1988) method for the preparation of the aqueous extracts, $500 \mathrm{~g}$ of the kernel powders (of the two pesticidal plants) were dissolved in 1 litre of distilled water. The mixture was homogenised every 2 hours for 24 hours at room temperature and filtered before testing. From the stock solution, four doses of each extract were prepared, i.e., 12.5, 25, 50 and $100 \mathrm{mg} / \mathrm{ml}$ for the aqueous extracts and the same concentrations in $\mu \mathrm{l} / \mathrm{ml}$ of sterile distilled water mixed with $0.01 \mathrm{~g}$ of soap powder for the oil extracts. The following formula of Gata-gonçalves (2003) was used to obtain these doses:

$$
\mathrm{CiVi}=\mathrm{CfVf}
$$

Ci: initial concentration; Vi: initial volume; $\mathbf{C f}$ : final concentration; Vf: final volume

These doses were compared with the chemical insecticide (positive control), pyriforce composed of chlorpyriphos-ethyl $600 \mathrm{~g} / \mathrm{l}$ at the recommended dose of $11 /$ ha (50 $\mathrm{ml}$ for a 16-litre sprayer) or $4.6 \mu$ lissolved in $1 \mathrm{ml}$ of sterile distilled water and with sterile distilled water (negative control) (Figure 3).
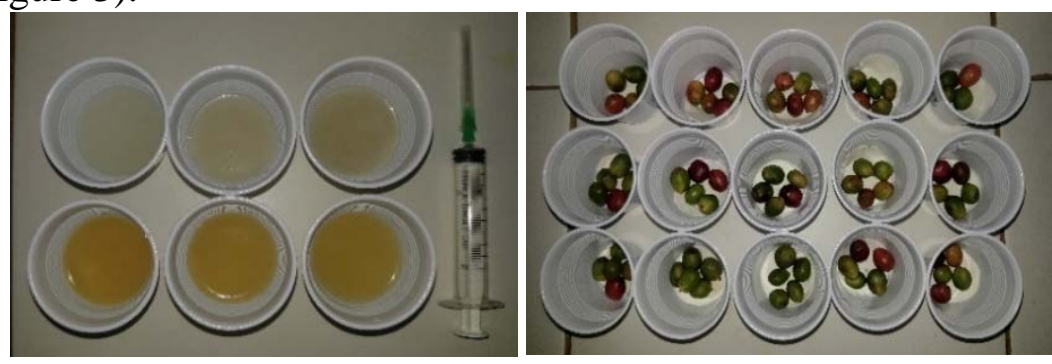

Figure 3. Preparation of Plant Extracts and Coffee Berries

\subsubsection{Toxicity and Anti-appetence Test by Direct Treatment of Bark Beetles}

Toxicity tests were carried out on approximately 450 non-sexed adult bark beetles with 120 insects for each type of extract. In $10 \mathrm{cl}$ volume boxes lined with cotton and absorbent paper, 10 insects previously cleaned (with a $1 \%$ solution of sodium hypochlorite and sterile distilled water) and soaked for 15 seconds in one of the concentration of the extracts (Butt \& Goettel, 2000), were placed at the bottom of the box with 10 coffee berries. Each treatment was repeated three times. Observations were made for 12 days, and that is enough time for the extracts to take effect before they lost their effectiveness. Twenty-four hours ( $24 \mathrm{~h}$ ) after the start of the experiment, dead bark beetles (recovered and pricked with the pin) and perforated berries were counted daily in each treatment. The experiment was repeated twice.

The corrected mortality (CM) was expressed according to Abbott's formula (1925): 


$$
C M=\frac{M t-M c}{100-M c} \times 100
$$

CM: corrected mortality; Mt: observed mortality in the different extract treatments; Mc: natural mortality in the control treatment

Similarly, the rate of attack or berry perforation by $H$. hampei was calculated using the following ratio:

$$
T a=\frac{N p b}{N t b} \times 100
$$

Npb: number of perforated berries; Ntb: total number of berries introduced at the beginning of the experiment

\subsubsection{Toxicity and Anti-appetence Test by Direct Treatment of the Berries}

For this test, the same number of insects was used as in the previous experiment. In this case, the berries were directly treated by dipping them in the different concentrations of the extracts and the number of dead insects and perforated berries were counted.

\subsection{Statistical Analysis}

Data were analysed using XLSTAT 2014 software. The cumulative and corrected mortality rates underwent angular transformations (ArcSin), and then by an analysis of variance (ANOVA) followed by a multiple comparison test of the Fisher means. The transformed mean values obtained were crossreferenced with the transformed concentrations in decimal logarithm (Jayarama, 1999). From these transformations, "arcsin-logarithmic" regression lines were generated of the type $y=a x+b(y=$ arsin of the mortality rate; $\mathrm{x}=$ logarithm of the concentration or time; $\mathrm{a}=$ slope of the regression line). From these regression equations, lethal concentrations causing 50 and 90\% mortality were determined by the maximum likelihood method (Lazar, 1968). A Principal Component Analysis (PCA) was carried out to determine the relationships between mortality rate, berry attack rate, and the mode of application of extracts.

\section{Results}

\subsection{Hunting and Breeding of Hypothenemus hampei in the Laboratory}

The hunting of bark beetles by picking berries infested with them resulted in the highest insect population (about $60 \pm 15.3$ insects on average per berry) compared to the insect population caught in traps, which was relatively low ( $4 \pm 0.2$ insects on average per trap every two days).

The breeding of bark beetles in the laboratory showed that the average number of insects produced (162.4 \pm 16.9$)$ is significantly higher with coffee berries than with groundnut kernels $(4.6 \pm 1.1)$ and maize $(2.8 \pm 0.8)$. The 
reproduction rate of the borer is 11 times higher with coffee berries than with other substrates where there is a loss of introduced insects at the start. The reproductive rate of the coffee berry borer is better for both females (144) and males (18.4), i.e., a sex ratio of 0.13 compared to groundnut (sex ratio $=0.39$ ) and maize $($ sex ratio $=0.64)($ Table 1$)$.

Table 1. Average Number of Hypothenemus hampei obtained after 43 Days of Rearing

\begin{tabular}{|c|c|c|c|c|}
\hline \multirow{2}{*}{\multicolumn{2}{|c|}{$\begin{array}{c}\text { Reproduction evaluation } \\
\text { parameters }\end{array}$}} & \multicolumn{3}{|c|}{ Substrate } \\
\hline & & \multirow{2}{*}{$\begin{array}{c}\text { Coffee Berries } \\
15\end{array}$} & \multirow{2}{*}{$\begin{array}{c}\begin{array}{c}\text { Groundnut } \\
\text { Kernels }\end{array} \\
15\end{array}$} & \multirow{2}{*}{$\begin{array}{c}\text { Maize Kernels } \\
15 \\
\end{array}$} \\
\hline Total & Start & & & \\
\hline number of & End & $162.4 \pm 16.9^{\mathrm{b}}$ & $4.6 \pm 1.1^{\mathrm{a}}$ & $2.8 \pm 0.8^{\mathrm{a}}$ \\
\hline $\begin{array}{c}\text { bark } \\
\text { beetles }\end{array}$ & Reproduction rate & $10.8 \pm 1.1^{\mathrm{b}}$ & $0.3 \pm 0.1^{\mathrm{a}}$ & $0.2 \pm 0.1^{\mathrm{a}}$ \\
\hline \multirow[t]{3}{*}{ Female } & Start & 10 & 10 & 10 \\
\hline & End & $144 \pm 11.9^{b}$ & $4.6 \pm 1.1^{\mathrm{a}}$ & $2.8 \pm 0.8^{\mathrm{a}}$ \\
\hline & Reproduction Rate & $14.4 \pm 1.2^{\mathrm{b}}$ & $0.5 \pm 0.1^{\mathrm{a}}$ & $0.3 \pm 0.1^{\mathrm{a}}$ \\
\hline \multirow[t]{3}{*}{ Male } & Start & 5 & 5 & 5 \\
\hline & End & $18.4 \pm 5.1^{\mathrm{b}}$ & $1.8 .10^{-15} \pm 0.0^{\mathrm{a}}$ & $\begin{array}{c}1.8 .10^{-15} \pm \\
0.0^{\mathrm{a}}\end{array}$ \\
\hline & Reproduction Rate & $3.7 \pm 1.0^{\mathrm{b}}$ & $0.0 \pm 0.0^{\mathrm{a}}$ & $0.0 \pm 0.0^{\mathrm{a}}$ \\
\hline \multicolumn{2}{|c|}{ Sex ratio at the End } & 0.13 & 0.39 & 0.64 \\
\hline \multicolumn{5}{|c|}{$\begin{array}{l}\text { The values of the same line with different letters are significantly different at } p<0.05 \\
\text { according to the Fisher test. }\end{array}$} \\
\hline
\end{tabular}

\subsection{Evaluation of the Toxicity and Anti-appetence of Extracts after Treatment of Bark Beetles}

The observation of Figure 4 shows that in general, the mortality of Hypothenemus hampei was strongly related $\left(\mathrm{R}^{2}=0.930\right.$ and $\left.\operatorname{Pr}<0.0001\right)$ to the treatments applied while the attack on the berries was moderately related $\left(\mathrm{R}^{2}=0.786\right.$ and $\left.\mathrm{Pr}<0.0001\right)$. Specifically, this mortality was strongly linked to aqueous extracts of $T$. peruviana kernel powder and the attack on the berries was linked to extracts of Azadirachta indica.

Analysis of insect mortality showed that aqueous extracts of $A$. indica kernel powder were very poorly effective against the bark beetle at any concentration, with rates ranging from $0 \%$ (C1 to C4) to $11.8 \%$ (C3). Aqueous extracts of Thevetia peruviana showed significantly average efficacy on bark beetle mortality. Mortalities were almost proportional to the concentrations applied, ranging from $0 \%(\mathrm{C} 2)$ to $94.9 \%$ of killed bark beetles (C4). Oil extracts of $A$. indica were more effective against the coffee berry borer; average mortality rates of 78.7, 90.7, and 100\% were observed for C3, C1, C2, and C4 respectively (Figure 4).

The berry attack was related to the treatments applied and the mortality rates of the coffee berry borer. All the treatments that caused high mortality of bark beetles had low rates of attack on coffee berries. Aqueous extracts of $A$. 
indica showed berry attack rates between 31.3 (C4) and 73\% (C2), while aqueous extracts of $T$. peruviana showed berry attack rates between $18 \%$ (C4) and $82.2 \%$ (C2). The oil extracts of A. indica showed berry attack rates between 0\% (C2 and C4) and 26\% (C3) while with distilled water the berry attack rate was $68 \%$ and $0 \%$ with pyriforce (Figure 4 ).

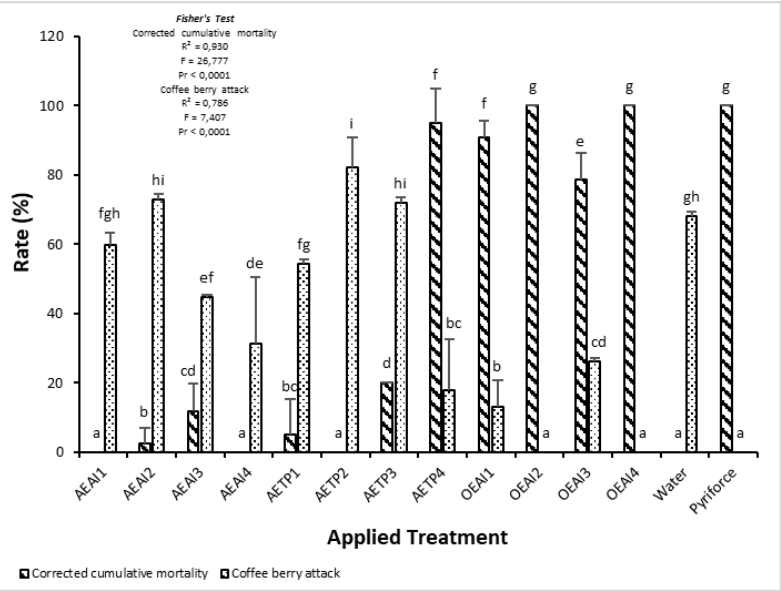

Figure 4. Corrected Cumulative Mortality Rate of Hypothenemus hampei and Coffee Berry Attack in Vitro under the Influence of Aqueous Extracts of Azadirachta indica, Thevetia peruviana and Pyriforce

AEAI: Aqueous extract of Azadirachta indica; AETP: Aqueous extract of Thevetia peruviana; OEAI: Oil extract of Azadirachta indica; Pyriforce: Insecticide composed of chlorpyrifos-ethyl $(4.6 \mu \mathrm{l} / \mathrm{ml}) ; \mathbf{1}, \mathbf{2}, 3$ and 4 correspond respectively to concentrations $12.5,25,50$ and $100 \mathrm{in} \mathrm{mg} / \mathrm{ml}$ for the aqueous extracts and in $\mu \mathrm{l} / \mathrm{ml}$ for the oil extract.

The values with different letters for the same variable are significantly different at the threshold $\alpha=0.05$ according to the Fisher test.

\subsection{Evaluation of the Toxicity and Repulsion of Extracts by Berry Treatments}

By treating the berries directly, $100 \%$ bark beetle mortality was obtained with the oil extracts of Azadirachta indica (C2, C3 and C4) and chlorpyrifos-ethyl for berry perforation rates of $11 \%$ (C2) and $0 \%$ (C3, C4 and Pyriforce) respectively. With the AETP4, 91\% mortality was observed for a berry perforation rate of $11 \%$. More than fifty percent mortality on average was observed with AEAI3 (55\%), AETP1 (59\%), AETP3 (61\%) and OEAI1 (79\%) for bay perforation rates of 33, 13, 19 and 7\% respectively. Average mortalities of less than $50 \%$ were obtained in water treatment (0\%), AEAI1 (16\%), AEAI4 (36\%), AEAI2 (39\%) and AETP2 (49\%) for average bay attack rates of 50, 39, 19, 40 and 10\%, respectively (Figure 5). 
In sum, mortality $\left(\mathrm{R}^{2}=64 \%\right.$; $\left.\operatorname{Pr}<0.0001\right)$ as well as berry attack $\left(\mathrm{R}^{2}=\right.$ $64 \%$; $\operatorname{Pr}<0.0001)$ were correlated to the treatments applied. Oil and aqueous extracts of $A$. indica and the chlorpyrifos-ethyl (Pyriforce) were the most effective treatments causing more than 50\% mortality except for AEAIT2. These are also the same treatments that protected about $80 \%$ of the coffee berries. However, no significant difference was observed between the mortality rates of the A. indica oil extract treatments (Figure 5).

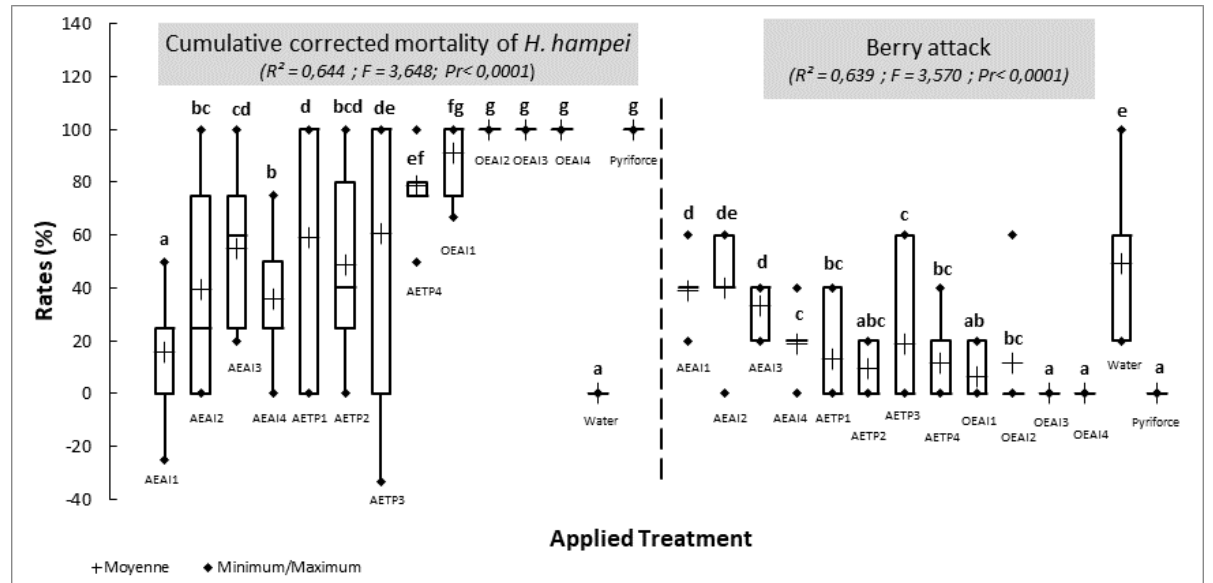

Figure 5. Mortality and Attack Rate of Hypothenemus hampei Berries in Vitro after Berry Treatment

AEAI: Aqueous extract of Azadirachta indica; AETP: Aqueous extract of Thevetia peruviana; OEAI: Oil extract of Azadirachta indica; Pyriforce: Insecticide composed of chlorpyrifos-ethyl $(4.6 \mu \mathrm{l} / \mathrm{ml}) ; 1,2,3$ and 4 correspond respectively to concentrations $25,50,75$ and $100 \mathrm{in} \mathrm{mg} / \mathrm{ml}$ for the aqueous extracts and in $\mu \mathrm{l} / \mathrm{ml}$ for the oil extract.

Values with different letters for the same variable are significantly different at the threshold $\alpha=0.05$ according to the Fisher test. Mortality $\left(\mathrm{R}^{2}=\right.$ 0.644; $\mathrm{F}=3.570 ; \mathrm{Pr}<0.0001)$ and Berry attack $\left(\mathrm{R}^{2}=0.639 ; \mathrm{F}=3.570 ; \mathrm{Pr}<\right.$ 0.0001).

\subsection{Relationship between Mortality of Hypothenemus hampei, Doses of Extracts of Thevetia peruviana and Azadirachta indica}

Adjustment of the cumulative corrected mortality rates of Hypothenemus hampei, according to the concentrations of aqueous extracts of Thevetia peruviana and aqueous and oil extracts of Azadirachta indica after 12 days of incubation, showed a very weak linear relationship between the concentrations of the AEAI $\left(\mathrm{R}^{2}=0.0231\right)$ and $\operatorname{OEAI}\left(\mathrm{R}^{2}=0.0589\right)$ treatments, a mean linear relationship between the concentrations of the AETP treatment $\left(\mathrm{R}^{2}=0.7002\right)$, and the mortality of bark beetles after treatment of the latter. The inverse logarithm (antilog) of the linear regression equation revealed that 
lethal concentrations causing $50\left(\mathrm{LC}_{50}\right)$ and $90 \%\left(\mathrm{LC}_{90}\right)$ bark beetle mortality were higher with aqueous extracts of $A$. indica (AEAI) than with aqueous extracts of $T$. peruviana (AETP). With the oil extracts of OEAI, the LC $\mathrm{C}_{50}$ was $0.0039 \mu \mathrm{l} / \mathrm{ml}$ while the $\mathrm{LC}_{90}$ was $5.134 \mu \mathrm{l} / \mathrm{ml}$ (Figure 6).

After treatment of coffee berries with plant extracts, the linear relationship between mortality of $H$. hampei and the concentrations of aqueous extracts of $A$. indica $\left(\mathrm{R}^{2}=0.20\right)$ and $T$. peruviana $\left(\mathrm{R}^{2}=0.21\right)$ was weak. This linear relationship was mean between bark beetle mortality and the concentrations of oil extracts of $A$. indica $\left(\mathrm{R}^{2}=0.6\right)$. In sum, it took about 25 times more aqueous extract of $A$. indica $\left(\mathrm{LC}_{50}=161.68 \mathrm{mg} / \mathrm{ml}\right)$ to kill fifty percent of bark beetles than aqueous extracts of $T$. peruviana $\left(\mathrm{LC}_{50}=6.49\right.$ $\mathrm{mg} / \mathrm{ml})$. The $\operatorname{LC}_{50}(0.13 \mu \mathrm{l} / \mathrm{ml})$ was even lower with A. indica oil to kill fifty percent of bark beetles. The same findings were made when $\mathrm{LC}_{90}$ was observed, where it took about 2.4 times A. indica extract to kill ninety percent of bark beetles compared to T. peruviana extracts. Application of the extracts to the berries had a faster effect on bark beetle mortality than direct application to the bark beetles (Figure 6).

After treatment of bark beetle
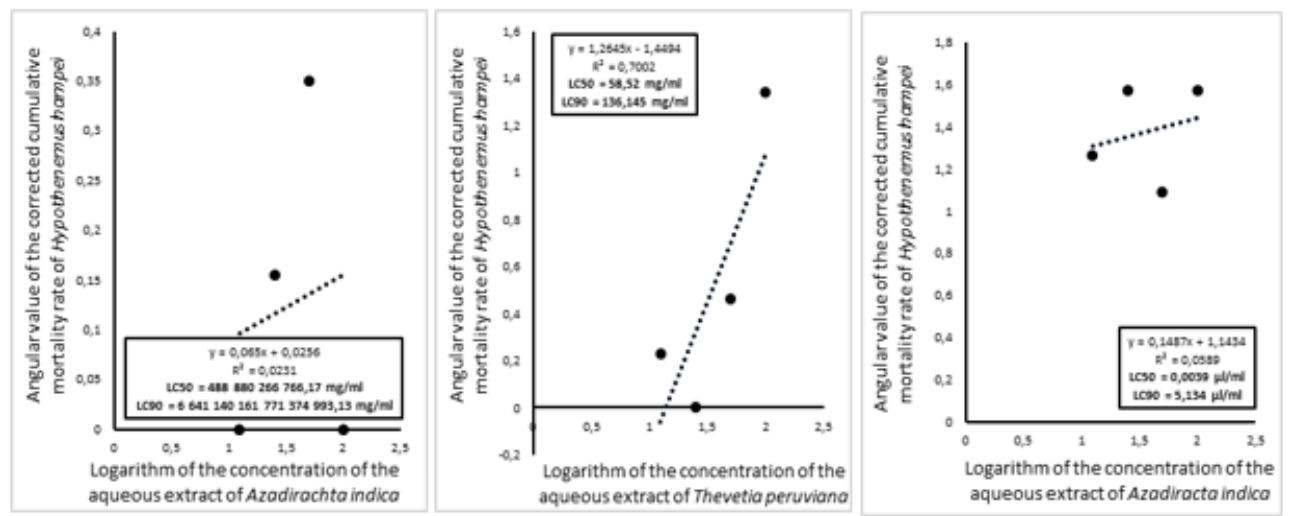

After treatment of the coffee berries
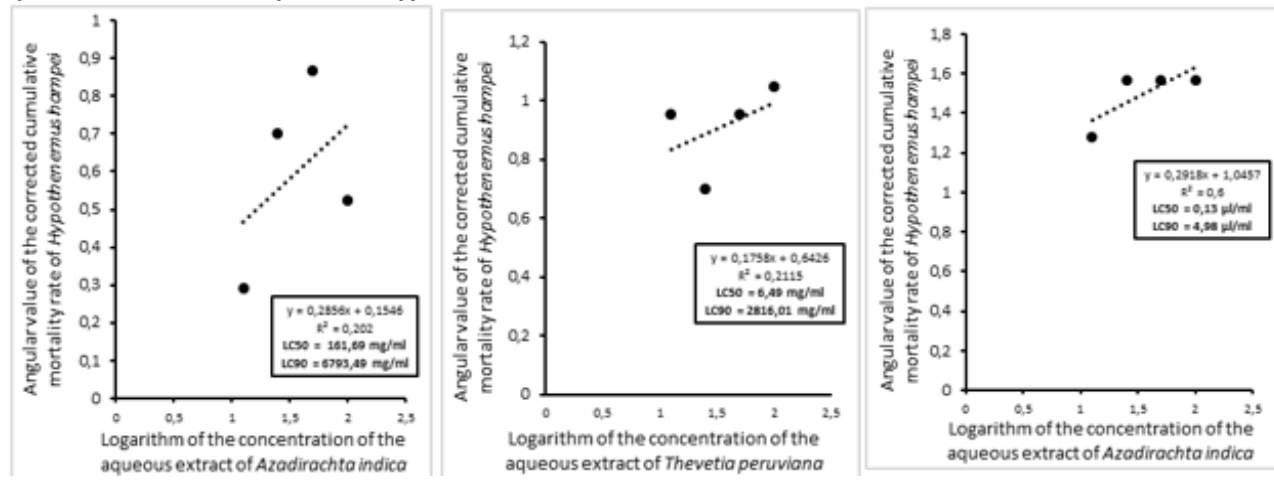

Figure 6. Linear Regression of the Angular Values of the Corrected Cumulative Mortality of Hypothenemus hampei as a Function of the Decimal Logarithms of the Extract Concentrations 
Arcsin-logarithm regression equation of type $y=a x+b$ where $y=$ arcsin of the percentage of the corrected cumulative mortality of $H$. hampei; $\mathrm{x}=$ logarithm of the $\mathrm{B}$. bassiana dose; $\mathrm{a}=$ slope of the line; $\mathrm{R}^{2}=$ the coefficient of determination.

\subsection{Influence of the Mode of Application of Treatments on their Effectiveness against Hypothenemus hampei}

Principal Component Analysis (PCA) of bark beetle mortality rates and berry attack rates, according to the modes of application of pesticide treatments, showed that the majority of treatments (pyriforce, OEAI1, OEAI2, OEAI4 and AETP4) that caused high mortality and low berry attack rates were effective by treating the bark beetles directly (Figure 7).

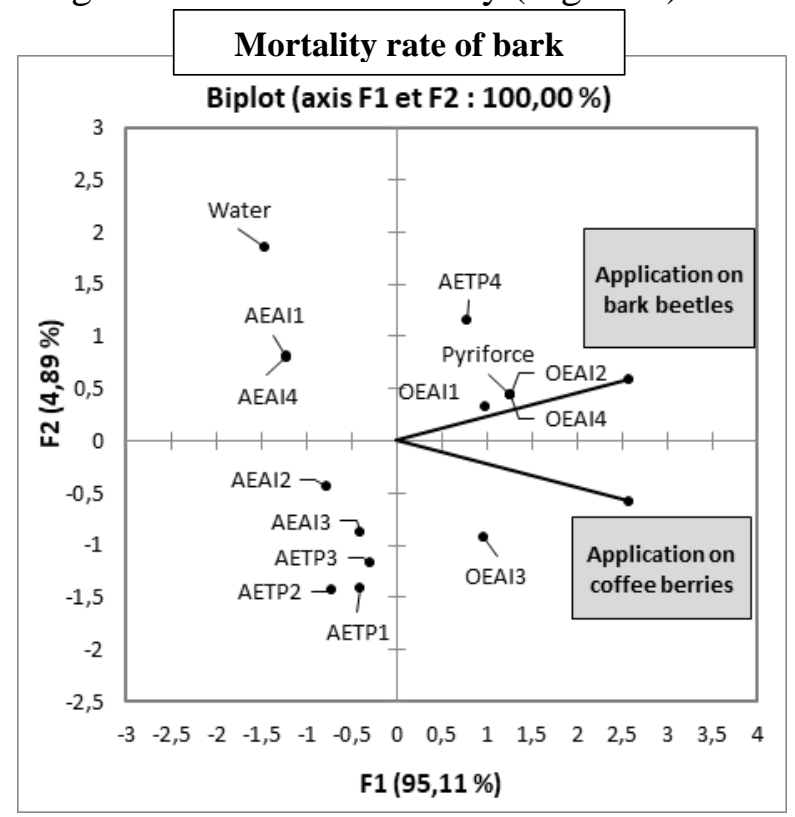

Figure 7. Analysis in main Components of the Modes of Application of the Different Treatments according to the Mortality of the Bark Beetles and the Attack Rates of the Berries

$\mathrm{AEAI}=$ Aqueous extract of Azadirachta indica; $\mathrm{AETP}=$ Aqueous extract of Thevetia peruviana; OEAI = Oil extract of Azadirachta indica; Pyriforce $=$ Insecticide composed of chlorpyrifos-ethyl; 1, 2, 3 and 4 correspond to C1 (12.5), C2 (25), C3 (50) and C4 (100) in $\mathrm{mg} / \mathrm{ml}$ for the aqueous extracts and in $\mu \mathrm{l} / \mathrm{ml}$ for the oil extract.

\section{Discussion}

At the end of this study, it was observed that sanitary harvesting of Hypothenemus hampei infested berries can be an effective solution to stop the infestation of plantations. This is because the bark beetle population obtained 
was better (60 \pm 15.3 coffee berry borers on average per berry) through the harvesting of infested berries in the field than through pheromone traps. This harvest eliminates all sources of food for the bark beetles and reduces the insect population in the field; a single berry can host 100 to 200 bark beetles as larvae, nymphs mostly adults according to Mahob et al. (2006) and Infante et al. (2014). However, this solution is costly in terms of final berry production, time, and energy for harvesting the infested berries and processing them (transport and destruction) (Dufour \& Frérot, 2008).

Reproduction of bark beetles has been better with coffee berries than with groundnut or maize kernels, confirming that coffee berries remain the preferred food source for $H$. hampei regardless of sex. A small population of bark beetles has been able to persist in groundnuts and maize. This showed that these substrates can help the survival of this insect and divert the attention of part of the bark beetle population from the coffee berries in a field. A similar observation was made by Damon (2000) and Vega et al. (2015), who noted that the borer can infest other crops in the absence of coffee berries. Attempts to rear this pest in the laboratory showed that it was good (162.4 borer beetles obtained at the end with coffee), but could be better if the number of females in the boxes was increased. Various authors report an average sex ratio of 10 female bark beetles to about one male (Cochereau \& Potiaroa, 1994). Green and semi-ripe berries have been used for the rearing of bark beetles; this phenological stage of the berries is better for the blossoming (nutrition and development) of the bark beetles, although the bark beetles do not distinguish these fruit stages according to their volatile compounds (Blassioli-Moraes et al., 2018). Furthermore, Mathieu et al. (1999) reveal that the fertility rate of the coffee berry borer is higher in over-ripe berries than in unripe berries.

The oil constituents of Azadirachta indica kernels such as azadirachtin are thought to be responsible for the insecticidal and anti-appetent effects observed on the coffee berry borer. A similar effect was obtained against the borer by Isman (2006), Mawussi (2008), Vijayalakshmi et al. (2014), Green et al. (2015), and Samy (2018). The constituents of Thevetia peruviana kernels, including cardenolides called thevetin A\&B and others including peruvosid, nerrifolin, thevetoxin and rivosid, would have the same effects as with A. indica oil and chlorpyriphos-ethyl. They act more effectively from the first days of direct contact with the bark beetles. Chougourou et al. (2012) showed that $T$. peruviana kernels were very rich in oil which has an insecticidal effect against Musca domestica as well as A. indica oil. Kernel extracts from these two plants contain compounds such as tannins, anthocyanins, saponins, sterols, and many other secondary metabolites that have strong antimicrobial and antifungal activity (Scalbert, 1999; Kosma et al., 2011; Mboussi et al., 2016). Comparison of LC50 and LC90 confirmed this 
finding by showing that more aqueous extract of A. indica kernels than $T$. peruviana or A. indica oil is required to cause fifty or ninety percent mortality. The majority of lethal concentrations were higher when the extracts were applied directly to the bark beetles than to the berries. Thus, the treatment of the berries would poison them and/or play a repellent role in attempts to feed the bark beetles causing them to starve themselves. This assertion is in line with the findings of Green et al. (2015) who found that aqueous extracts of $A$. indica kernel powders had a significant repellent effect against coffee berry borer insects. Similarly, the results obtained with A. indica oil are similar with those of Depieri and Martinez (2010) and Celestino et al. (2016) who showed that this oil caused high mortality of bark beetles and provided protection of coffee berries.

The presence of unperforated berries and the absence of mortality were noted with sterile distilled water and at high concentrations of certain treatments. One explanation could be that the insect sex ratio was not applied. The majority of berries are perforated by the females when they go to lay eggs and these are followed by the males after their entry. This would have had a considerable effect if the insect populations used for the tests consisted mostly of females that would have entered the berries before being influenced by the extracts. The males would have followed females into the same berries resulting in low berry attack rates, the presence of unperforated berries, in some treatments and particularly in water treatment. Depieri and Martinez (2010) and Celestino et al. (2016) showed that by spraying only female bark beetles and berries with $1 \%(\mathrm{v} / \mathrm{v})$ neem oil, they obtained about $80 \%$ bark beetle mortality and very few berry attacks.

\section{Conclusion}

Coffee berries remain the food of choice for the coffee berry borer, Hypothenemus hampei. The alternatives such as groundnuts or maize would divert very little attention from the coffee berry borer if these crops were combined with coffee in the field. However, these two crops have been shown to help a small population of bark beetles to survive during breeding, rather than to reproduce in the absence of coffee berries. Oil extracts of Azadirachta indica and aqueous extracts of Thevetia peruviana had a better insecticidal effect than aqueous extracts of $A$. indica kernel powders which had little or no effect against adult beetles. By directly poisoning coffee berries or borer, the mortality and attack rates of the berries were high, but slightly better after direct treatment of the borers. A. indica oil and aqueous extracts of $T$. peruviana could therefore be used in the same way as chlorpyrifos-ethyl in the protection of coffee plants against $H$. hampei. It would be interesting to investigate the effects of these two plants in the natural environment. 


\section{Acknowledgements}

The authors are grateful to the International Foundation for Science (IFS) in Sweden [Research Grant Agreement No. I-1-C-6256-1] and the International Centre for Agricultural Research for Development (CIRAD) through the DP/Agroforestry in Cameroon for their financial support. The authors are grateful to the Institute of Agricultural Research for Development (IRAD) for technical assistance.

\section{References:}

1. Abbott, W.S. (1925). A Method for Computing the Effectiveness of an Insecticide. Journal of Economic Entomology, 18: 265-267.

2. Agence ecofin (2020). L'industrie camerounaise du café. https://www.agenceecofin.com/agro/1507-78548-lindustriecamerounaise-du-cafe-infographie. Page created on July 15, 2020 and accessed on December 17, 2020.

3. Amang-Mbang J., Mounjouenpou P., Mahob R. J., Mbarga Amougou M., Mouen Bedimo, J. \& Nyasse, S. (2012). Evaluation naturelle de l'impact de Beauveria bassiana : Champignon entomopathogène dans la dynamique de population de Hypothenemus hampei, scolyte de baies des cerises de Coffea canefora. African Crop Science Journal, 20: 443-451.

4. Anonymous (2014). Plan de relance et de développement des filières cacao et café du Cameroun. Cellule technique de suivi et de coordination des filières cacao et café, services du Premier Ministre de la République du Cameroun, 106 p.

5. Aristizabal, L. F., Lara, O. \& Arthurs, S. P. (2012). Implementing an Integrated Pest Management Program for Coffee Berry Borer in a Specialty Coffee Plantation in Colombia. Journal of Integrated Pest Management, 3(1): 1-5.

6. Bayiha, G. P., Temple, L. \& Mathé, S. (2020). Diversité des trajectoires de l'agriculture biologique au Cameroun. Systèmes alimentaires / Food Systems, Classic Garnier ed., 5: pp. 181-204.

7. Blassioli Moraes, M. C., Michereff, M. F. F., Magalhães, D. M., Morais, S. D., Hassemer, M. J., Laumann, R. A., Meneghin, M. A., Birkett, D. M., Withall, J. N., Medeiros, C. M., Corrêa, C. \& Borges, M. (2018). Influence of Constitutive and Induced Volatiles from Mature Green Coffee Berries on the Foraging Behaviour of Female Coffee Berry Borers, Hypothenemus hampei (Ferrari) (Coleoptera: Curculionidae: Scolytinae). Arthropod-Plant Interactions, 13: 349358.

8. Butt, T. M. \& Goettel, M. S. (2000). Bioassays of Entomopathogenic Microbes and Nematodes. K.R.S. CABI Publishing, New York. 320 p. 
9. Celestino, F. N., Pratissoli, D., Machado L. C., Gonçalves, S. J. H. J., Vagner, T. Q. \& Mardgan, L. (2016). Control of Coffee Berry Borer, Hypothenemus hampei (Ferrari) (Coleoptera: Curculionidae: Scolytinae) with Botanical Insecticides and Mineral Oils. Acta Scientiarum. Agronomy Maringá, 38(1): 1-8.

10. Chougourou, C. D., Dellouh, P. L., Agbaka, A., N'guessan, K. R. \& Gbenou, J. D. (2012). Toxicité et effets répulsifs de certaines huiles extraites des plantes locales béninoises sur la mouche domestique Musca domestica L. (Diptera: Muscidae). Journal of Applied Biosciences, 55: 3953-3961.

11. Cochereau, P. \& Potiaroa, T. (1994). Lutte biologique contre le scolyte de la graine du caféier Hypothenemus hampei Ferr. (Coleoptera : Scolytidae) en Nouvelle-Calédonie. Fonds documentaire ORSTOM, cote : B*5341, Ex : 1.32 p.

12. Damon, A. (2000). Review of the Biology and Control of Coffee Berry Borer, Hypothenemus hampei Ferrari (Coleoptera: Scolytidae). Bulletin of Entomological Research, 90: 453-465.

13. Depieri, R. A. \& Martinez, S. S. (2010). Redução da sobrevivência da broca-do-café, Hypothenemus hampei (Ferrari) (Coleoptera: Scolytidae), e do seu ataque aos frutos de café pela pulverização com nim em laboratório. Neotropical Entomology, 39(4): 632-637.

14. Dufour, B. P. \& Frérot, B. (2008). Optimization of Coffee Berry Borer, Hypothenemus hampei Ferrari (Coleoptera: Scolytidae), Mass Trapping with an Attractant Mixture. Journal of Applied Entomology, 132: 591-600.

15. Gata-Gonçalves, L., Nogueira, J. M. F., Matos, O. \& Bruno De Sousa, R. (2003). Photoactive Extract from Thevetia peruviana with Antifungal Properties against Cladosporium cucumerinum. Journal of Photochemistry and Photobiology, 70(1): 51-54.

16. Green Paul, W. C., Davis, A. P., Cossé, A. A. \& Vega, F. E. (2015). Can Coffee Chemical Compounds and Insecticidal Plants be harnessed for Control of Major Coffee Pests? Journal of Agricultural and Food Chemistry, 63(43): 9427-34.

17. Infante, F., Pérez, J. \& Vega, F. (2014). The Coffee Berry Borer: The Centenary of a Biological Invasion in Brazil. Brazilian Journal of Biology, 74: 125-126.

18. Institut de Recherche Agricole pour le Développement (IRAD) (2008). Rapport national sur la situation des ressources phylogénétiques pour l'alimentation et l'agriculture au Cameroun. 93 p.

19. Isman, M. B. (2006). Botanical Insecticides, Deterrents and Repellents in Modern Agriculture and an Increasingly Regulated World. Annual Review of Entomology, 51: 45-66. 
20. Jayarama, K. (1999). Manuel de statistique pour la recherche forestière. Organisation des nations unies pour l'alimentation et l'agriculture (FAO), $242 \mathrm{p}$.

21. Kosma, P., Ambang, Z., Begoude, B. A. D., Ten Hoopen, G. M., Kuate, J. \& Amougou, A. (2011). Assessment of Nematicidal Properties and Phytochemical Screening of Neem Kernel Formulations using Radopholus similis Parasitic Nematode of Plantain in Cameroon. Crop protection, 30: 733-738.

22. Lazar, P. (1968). Les essais biologiques. Revue de statistique appliquée, Société française de statistique, 16(3): 5-35.

23. Mahob, R., Babin, R. \& Dibog, L. (2006). Test de piège Brocap au Cameroun, pour améliorer la lutte contre le scolyte des baies du caféier Hypothenemus hampei (Coleoptera : Scolytidae), in : Bella Manga, Kamga André, Omokolo Ndoumou D., Havard Michel éd., Atelier de présentation des résultats des opérations de recherche participative, 2123 février, Yaoundé, Cameroun. Cirad - Agritop, https://agritop.cirad.fr/540864/. Page accessed on October 03, 2019.

24. Mathieu, F., Brun, L. O., Frérot, B., Suckling, D. M. \& Frampton, C. (1999). Progression in Field Infestation is linked with Trapping of Coffee Berry Borer, Hypothenemus hampei (Coleoptera: Scolytidae). Journal of Applied Entomology, 123: 535-540.

25. Mawussi, G. (2008). Bilan environnemental de l'utilisation de pesticides organochlorés dans les cultures de coton, café et cacao au Togo et recherche d'alternatives par l'évaluation du pouvoir insecticide d'extraits de plantes locales contre le scolyte du café (Hypothenemus hampei Ferrari). Thèse de Doctorat, l'Institut National Polytechnique de Toulouse, Université de Toulouse, France. 207 p.

26. Mbondji, M. P. (1988). Etude épidémiologique d'Hypothenemus hampei (Coleoptera : Scolytidae), ravageur des baies du caféier, dans deux régions du Cameroun. Naturaliste canadien, (Review of Ecology, Evolution and Systematics, 115: 245-249.

27. Mboussi, S. B., Ambang, Z., Ndogho, A., Ngoh Dooh, J. P. \& Manga Essouma, F. (2016). In Vitro Antifungal Potential of Aqueous Kernels Extracts of Azadirachta indica and Thevetia peruviana against Phytophthora megakarya in Cameroon. Journal of Applied Life Sciences International, 4(4): 1-12.

28. Ministère de l'Économie et de la Planification du Territoire (MINEPAT), République du Cameroun (2009). Document de stratégie pour la croissance et l'emploi (DSCE 2010-2020), Cameroun, 167 p.

29. Nguema Ndoutoumou, P., Ondo Ovono, P., Gatarasi, T. \& Okoumba, J. S. O. (2015). Effet des extraits de Jatropha curcas L. et de Tabernanthe iboga Baill. dans la lutte contre le scolyte du caféier 
(Hypothenemus hampei Ferrari) au Sud-Est du Gabon. International Journal of Biological and Chemical Sciences, 9(6): 2764-2775.

30. PAN Germany (2008). Introduction progressive d'alternatives à l'endosulfan. PAN International, Hambourg. 8 p.

31. Perez-Lachaud, Hardy, I. C. W. \& Lachaud, J. P. (2002). Insect Gladiators: Competitive Interactions between Three Species of Bethylid Wasps Attacking the Coffee Berry Borer, Hypothenemus hampei (Coleoptera: Scolytidae). Biological Control Journal, 25: 231238.

32. Samy, M. A. (2018). The Potential of Neem, Pongamia Oil and Garlic Extracts Formulation for an Effective Management of Berry Borers in Organic Coffee Plants. International Journal of Food and Bioscience, 1(1): 49-55.

33. Scalbert, A. (1999). Antimicrobial Properties of Tannins. Phytochemistry, 20: 875-883.

34. Stoll, G. (1988). Protection naturelle des végétaux en zones tropicales. AGRECOL- Centre Technique de Coopération Agricole (CTA) Ed. Josef Margraf. 97985 Weikersheim (Allemagne), 180 p.

35. Vega, F. E., Infante, F. \& Johnson, A. J. (2015). Chapter 11. The Genus Hypothenemus, with Emphasis on H. hampei, the Coffee Berry Borer, in: Vega F. E., Hoffstetter R. W. eds., Bark Beetles. Biology and Ecology of Native and Invasive Species. Academic Press, Elsevier. London, UK, pp. 427-494.

36. Vijayalakshmi, C. K., Tintumol, K. \& Vinodkumar, P. K. (2014). Effect of few Commercial Neem-Based Insecticides in the Management of Coffee Berry Borer, Hypothenemus hampei Ferrari (Coleoptera: Curculionidae). The Journal of Zoology Studies, 1(1): 2225. 